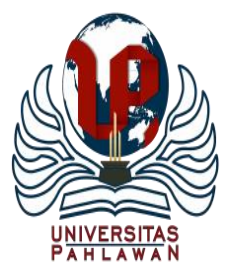

Edukatif : Jurnal Ilmu Pendidikan Volume 3 Nomor 4 Tahun 2021 Halm 1568 - 1577

EDUKATIF: JURNAL ILMU PENDIDIKAN

Research \& Learning in Education

https://edukatif.org/index.php/edukatif/index

\title{
Pengaruh Motivasi Belajar dan Lingkungan Belajar Terhadap Hasil Belajar Mata Pelajaran Ekonomi Siswa Saat Pembelajaran Daring
}

\author{
Heru Jaka Pratama1, Muhammad Abdul Ghofur ${ }^{2 \bowtie}$ \\ Universitas Negeri Surabaya, Indonesia ${ }^{1,2}$ \\ E-mail : heru.17080554048@ mhsunesa.ac.id ${ }^{1}$, muhammadghofur@ unesa.ac.id ${ }^{2}$
}

\begin{abstract}
Abstrak
Banyak yang mempertanyakan efektivitas pembelajaran daring, terutama mengenai hasil belajar siswa. Penelitian korelasional ini bertujuan untuk menganalisis variabel motivasi belajar dan lingkungan belajar terhadap hasil belajar siswa saat pembelajaran daring. Subyek penelitian ini adalah siswa kelas X Labschool Unesa. Data primer diperoleh dengan cara menyebar kuesioner kepada responden dan data nilai Penilaian Harian Bersama. Analisis data menggunakan regresi berganda. Hasil penelitian menunjukkan adanya pengaruh positif dan signifikan motivasi belajar dan lingkungan belajar terhadap hasil belajar siswa. Temuan ini penting dalam pembelajaran di masa pandemi.
\end{abstract}

Kata Kunci: Motivasi Belajar, Lingkungan Belajar, Hasil Belajar

\begin{abstract}
Many question the effectiveness of online learning, especially regarding student learning outcomes. This correlational study aims to analyze the variables of learning motivation and learning environment on student learning outcomes when learning online. The subjects of this study were students of class X Labschool Unesa. Primary data was obtained by distributing questionnaires to respondents and data on the value of the Joint Daily Assessment. Data analysis using multiple regression. The results showed that there was a positive and significant influence on learning motivation and learning environment on student learning outcomes. These findings are important in learning during a pandemic.
\end{abstract}

Keywords: learning motivation, learning environment, learning outcomes

Copyright (c) 2021 Heru Jaka Pratama, Muhammad Abdul Ghofur

Corresponding author:

Email : muhammadghofur@unesa.ac.id

DOI $\quad:$ https://doi.org/10.31004/edukatif.v3i4.621

ISSN 2656-8063 (Media Cetak)

ISSN 2656-8071 (Media Online)

Edukatif : Jurnal Ilmu Pendidikan Vol 3 No 4 Tahun 2021 p-ISSN 2656-8063 e-ISSN 2656-8071 
1569 Pengaruh Motivasi Belajar dan Lingkungan Belajar Terhadap Hasil Belajar Mata Pelajaran Ekonomi Siswa Saat Pembelajaran Daring - Heru Jaka Pratama, Muhammad Abdul Ghofur

DOI: https://doi.org/10.31004/edukatif.v3i4.621

\section{PENDAHULUAN}

Saat ini nyaris semua negara termasuk Indonesia dihadapkan dengan permasalahan kesehatan yang sama yakni virus bernama Covid-19. Penyebaran yang sangat cepat dengan penambahan jumlah pasien setiap harinya membuat pemerintah harus menerapkan kebijakan guna memutus rantai penyebarannya, salah satunya adalah kebijakan yang dikeluarkan oleh Gubernur Jawa Timur di bidang pendidikan dengan memberikan surat edaran kepada seluruh kepala instansi pendidikan untuk menerapkan pembelajaran dari rumah (School From Home) yang dimulai sejak tanggal 16 Maret 2020 dan masih berlaku hingga saat ini (Parawansa, 2020). Untuk itu pembelajaran daring merupakan solusi terbaik dalam menjaga kelangsungan kegiatan belajar mengajar di masa pandemi ini (Chung, Subramaniam, et al., 2020).

Menurut Mustofa (2019) pembelajaran daring adalah pembelajaran yang dilakukan jarak jauh dimana aktivitas pengajaran dan aktivitas belajar dilakukan secara terpisah. Pembelajaran daring merupakan pendidikan yang menggunakan satu atau lebih teknologi untuk menyampaikan pengajaran kepada siswa yang terpisah dari guru dan untuk mendukung interaksi antara siswa dan guru secara sinkron atau asinkron (Ginder $\&$ Stearns, 2014).

Hampir seluruh lembaga pendidikan di dunia termasuk siswa dan guru di dalamnya merasakan krisis perubahan yang tidak pernah terjadi sebelumnya di masa pandemi ini (Chung, Noor, et al., 2020). Terlebih di Indonesia yang seluruh lembaga sekolah formalnya masih menerapkan pembelajaran tatap muka. Meskipun sebenarnya pembelajaran daring sudah harus dilaksanakan di dalam bidang pendidikan pada akhir-akhir ini (He et al., 2019). Namun ternyata efektivitasnya belum dapat dirasakan, terbukti oleh penelitian yang dilakukan oleh Sahu (2020), selama pandemi ini siswa mengalami penurunan kualitas belajar. Permasalahan ini juga terjadi di Kelas X Labschool Unesa, hasil belajarnya masih sangat kurang dari yang diharapkan. Terlihat dari nilai PHB (Penilaian Harian Bersama) atau yang lebih dikenal dengan istilah UTS (Ulangan Tengah Semester) mata pelajaran Ekonomi Tahun ajaran 2020/2021 dari total 30 siswa hanya 4 di antaranya yang mampu melampaui nilai 77 (KKM). Artinya lebih dari $86 \%$ siswa mendapat hasil belajarnya belum mencapai kriteria minimal yang harus dicapai.

Kemampuan berupa kognitif kemudian afektif dan psikomotorik yang didapat siswa setelah melalui kegiatan pembelajaran disebut hasil belajar (Aminah, 2018). Hasil belajar kognitif merupakan fokus dari penelitian ini. Hasil belajar kognitif adalah kemampuan siswa untuk mempelajari suatu konsep yang dibuktikan dengan besaran perolehan nilai setelah melewati serangkaian tes yang diberikan (Susanto, 2013). Hasil belajar sama dengan prestasi belajar yaitu berupa nilai yang diperoleh pada periode tertentu (Negoro, 2004).

Penelitian ini menggunakan Teori Atribusi sebagai landasan teori. Pada dasarnya Teori Atribusi merupakan suatu pendekatan kognitif yang digunakan untuk menjelaskan penyebab perilaku seseorang termasuk perilaku berprestasi atau keberhasilan dalam memperoleh hasil belajar di sekolah (O'Sullivan \& Howe, 1996) dalam (Rosleny, 2008). Teori Atribusi yang digunakan adalah milik Harold Kelley yaitu atribusi kausalitas yang memfokuskan pada pertanyaan apakah faktor internal atau eksternal yang menyebabkan perilaku seseorang (Samsuar, 2019). Perilaku seseorang di sini dinyatakan dalam bentuk hasil belajar siswa.

Faktor internal yang sangat mungkin mempengaruhi hasil belajar salah satunya adalah motivasi belajar. Motivasi merupakan dorongan yang membuat siswa memiliki semangat tinggi untuk mencapai prestasi (Tu'u, 2004). Siswa dengan motivasi belajar rendah akan memiliki hasil belajar rendah juga. Motivasi belajar memiliki kemungkinan untuk meningkatkan hasil belajar siswa karena berfungsi sebagai pendorong siswa dalam belajar (Sardiman, 2011). Dalam Teori Behaviorisme motivasi sangat penting untuk mendorong siswa menunjukkan perilaku atau hasil belajar yang diharapkan. Motivasi siswa timbul akibat dari stimulus dan penguatan yang diberikan maupun dari keinginan siswa sendiri untuk dapat memahami sesuatu atau mendapatkan hasil belajar yang ia harapkan. 
1570 Pengaruh Motivasi Belajar dan Lingkungan Belajar Terhadap Hasil Belajar Mata Pelajaran Ekonomi Siswa Saat Pembelajaran Daring - Heru Jaka Pratama, Muhammad Abdul Ghofur

DOI: https://doi.org/10.31004/edukatif.v3i4.621

Djamarah (2015) mengemukakan bahwa ada 2 sudut pandang yaitu motivasi intrinsik dan ekstrinsik. Berbagai motif dalam diri individu yang mendorong untuk mengerjakan sesuatu disebut motivasi intrinsik. Sedangkan segala motif yang muncul akibat pengaruh atau dorongan dari luar individu disebut motivasi ekstrinsik.

Uno (2016) menjabarkan motivasi dalam belajar memiliki indikator-indikator yaitu yang pertama memiliki keinginan untuk sukses, kedua merasa butuh untuk belajar, ketiga memiliki cita-cita dan harapan, keempat ada penghargaan ketika belajar, kelima ada kegiatan menarik saat dan yang keenam lingkungan tempat belajar kondusif.

Penelitian Nafisah dkk. (2015) mengemukakan bahwa motivasi merupakan satu faktor di antara lainnya yang termasuk paling berpengaruh terhadap hasil belajar sebab siswa akan senantiasa berusaha untuk melakukan berbagai kegiatan yang mendukung proses belajarnya dan menjauhi kegiatan yang mengganggu proses belajarnya apabila motivasi belajarnya tinggi.

Penelitian Islamiyah (2019) juga menunjukkan pengaruh yang positif serta signifikan terhadap hasil belajar karena motivasi sebagai alat untuk menyaring mana saja kegiatan yang sesuai dengan tujuannya dan yang bukan.

Selanjutnya penelitian Efriza dkk. (2020) juga menemukan pengaruh positif serta signifikan dari motivasi belajar kepada hasil belajar sebab motivasi adalah jalan guna memperbaiki hasil belajar. Motivasi juga membuat siswa lebih fokus dan konsentrasi serta menimbulkan kebahagiaan.

Namun penelitian Gunawan dkk. (2018) mengemukakan sebaliknya yakni motivasi tidak mempengaruhi hasil belajar secara signifikan. Tidak dijelaskan mengapa terjadi demikian sehingga diperlukan pendalaman berupa penelitian lanjutan.

Begitu pula penelitian oleh Wijaya dan Bukhori (2017) juga menunjukkan pengaruh motivasi belajar tidak signifikan terhadap hasil belajar siswa. Motivasi yang tinggi tidak ada gunanya tanpa adanya usaha. Siswa yang memiliki motivasi rendah belum tentu lebih jelek hasil belajarnya daripada siswa dengan motivasi tinggi karena motivasi saja tidak cukup untuk meningkatkan hasil belajar.

Keseluruhan penelitian terdahulu yang dipaparkan di atas memiliki perbedaan dengan penelitian ini dalam segi kondisi dan waktu pelaksanaannya. Penelitian ini dilaksanakan saat dalam masa pandemi Covid-19 dimana seluruh pembelajaran tatap muka dialihkan menjadi pembelajaran daring, sedangkan penelitian terdahulu di atas dilaksanakan sebelum masa pandemi dimana pembelajarannya masih secara tatap muka. Penelitian ini nantinya akan memberikan kontribusi terhadap penelitian-penelitian sebelumnya berupa apakah motivasi belajar mempengaruhi hasil belajar siswa pada saat pembelajaran daring secara penuh.

Selanjutnya lingkungan belajar merupakan faktor eksternal yang mungkin untuk berpengaruh kepada hasil belajar. Apa pun di alam sekitar yang mempengaruhi seseorang disebut lingkungan (Hamalik, 2012). Dalam Teori Kognitif maupun Teori Behaviorisme sama-sama sepakat bahwa belajar tidak lepas dari interaksi siswa dengan lingkungannya. Menurut Teori Kognitif pengetahuan dalam diri individu adalah akibat dari interaksi dengan lingkungan secara berkelanjutan. Kemudian dalam Teori Behaviorisme berubahnya tingkah laku siswa akibat interaksi dengan lingkungannya disebut belajar. Menurut Winkel (1996) belajar adalah aktivitas psikis berupa interaksi terhadap lingkungan secara aktif yang mengakibatkan pengetahuan, pemahaman, nilai serta sikap mengalami perubahan yang tercermin dari hasil belajar. Sehingga semakin baik lingkungan seseorang makin baik juga hasil belajarnya.

Slameto (2013) membagi lingkungan belajar ke dalam 3 dimensi yakni lingkungan keluarga, sekolah dan masyarakat. Selanjutnya masing-masing dimensi tersebut memiliki indikator yakni indikator lingkungan keluarga yakni : 1) cara orang tua mendidik anak, 2) hubungan di antara personel keluarga dan 3) perhatian orang tua kepada anak. Selanjutnya indikator lingkungan sekolah berupa : 1) kedekatan siswa terhadap guru, 2) kedekatan diantara siswa, 3) metode belajar dan alat pembelajaran. Yang terakhir indikator lingkungan 
1571 Pengaruh Motivasi Belajar dan Lingkungan Belajar Terhadap Hasil Belajar Mata Pelajaran Ekonomi Siswa Saat Pembelajaran Daring - Heru Jaka Pratama, Muhammad Abdul Ghofur

DOI: https://doi.org/10.31004/edukatif.v3i4.621

masyarakat yaitu : 1) kegiatan masyarakat yang diikuti anak, 2) teman di rumah, 3) gaya hidup masyarakat sekitar dan media massa.

Penelitian Anggraini dkk. (2017) Menunjukkan jika lingkungan belajar memiliki tingkat kontribusi yang signifikan kepada hasil belajar karena hakikatnya belajar merupakan proses individu berinteraksi dengan lingkungannya sehingga lingkungan sangat penting untuk menaikkan hasil belajar.

Selanjutnya penelitian oleh Silvia dkk. (2018) Menemukan bahwa hasil belajar dipengaruhi oleh lingkungan belajar secara positif. Lingkungan belajar dengan kondisi nyaman serta kondusif merupakan tulang punggung dan pendorong proses pembelajaran berjalan dengan baik dan lancar. Apabila lingkungan belajar baik maka akan baik pula hasil belajarnya.

Sejalan dengan hal tersebut Nurdin dan Munzir (2019) memperoleh data bahwa lingkungan belajar mempengaruhi hasil belajar secara signifikan. Siswa bisa belajar maksimal apabila lingkungan belajarnya baik. Lingkungan belajar harus ditata sedemikian rupa hingga menjadi baik agar hasil belajar siswa baik pula.

Penelitian oleh Afrinaval dan Syamwil (2019) juga menemukan pengaruh yang positif serta signifikan dari lingkungan belajar kepada hasil belajar. Lingkungan belajar penting untuk diperhatikan apakah memberi pengaruh positif terhadap proses belajar siswa ataukah justru memberi pengaruh negatif. Keluarga, sekolah dan masyarakat pun bersama-sama harus mendukung penuh dalam menciptakan lingkungan yang baik agar tidak mengganggu dan menimbulkan hambatan dalam belajar siswa.

Terakhir penelitian Hermawan dkk. (2020) memaparkan hasil demikian : 1) ada pengaruh positif serta signifikan dari lingkungan keluarga kepada hasil belajar. Lingkungan keluarga yang nyaman dan mendukung serta hubungan antar anggota keluarga yang baik ditambah berbagai hal pendukung di dalamnya akan meningkatkan hasil belajar. Begitu pula apabila lingkungan keluarga dan aspek di dalamnya tidak cukup baik maka hasil belajar akan turun. 2) lingkungan kampus berpengaruh positif serta signifikan terhadap hasil belajar. Lingkungan sekolah yang kondusif serta memiliki kriteria baik dapat membuat mahasiswa menjadi nyaman untuk belajar. Selain itu cara mengajar dosen, ketepatan waktu belajar, fasilitas serta sarana dan prasarana akan berdampak pada peningkatan hasil belajar mahasiswa. 3) hasil belajar dipengaruhi secara positif serta signifikan oleh lingkungan masyarakat. Semakin bagus lingkungan masyarakat yang dimiliki seorang mahasiswa yang mencakup berbagai hal di dalamnya maka akan semakin bagus pula hasil belajarnya. Penurunan hasil belajar sangat bisa dipengaruhi oleh lingkungan masyarakat yang kurang bagus. Selanjutnya lingkungan keluarga, kampus dan masyarakat secara simultan juga memiliki pengaruh positif serta signifikan kepada hasil belajar karena memang ketiga aspek tersebut tidak dapat dipisahkan.

Penelitian berbeda secara mendasar dengan beberapa penelitian terdahulu di atas yakni kondisi pada saat penelitian dilakukan. Pada penelitian terdahulu pembelajaran dilaksanakan dengan tatap muka, namun pada penelitian ini pembelajaran dilaksanakan secara daring. Penelitian ini akan menunjukkan apakah pengaruh lingkungan belajar yakni berupa lingkungan keluarga, lingkungan sekolah dan lingkungan masyarakat terhadap hasil belajar daring di masa pandemi ini.

Sebenarnya ada banyak faktor internal dan eksternal yang mempengaruhi hasil belajar, namun penelitian ini memfokuskan kepada faktor internal berupa motivasi dan faktor eksternal berupa lingkungan belajar untuk melihat pengaruhnya terhadap hasil belajar mata pelajaran Ekonomi siswa kelas X IPS SMA Labschool Unesa pada saat pembelajaran daring di masa pandemi.

\section{METODE PENELITIAN}

Penelitian ini termasuk jenis penelitian terapan yang bertujuan korelasional dengan metode kuantitatif. Penelitian terapan berfungsi meneliti suatu permasalahan, situasi maupun fenomena tertentu dengan menggunakan teknik, prosedur dan metode penelitian guna membuat sebuah kebijakan atau meningkatkan pemahaman dari suatu fenomena (Ghofur, 2019). 
Metode kuantitatif merupakan metode dalam penelitian yang digunakan dalam menguji sebuah teori dengan mencari hubungan antar variabel biasanya melalui instrumen penelitian sehingga menghasilkan data berupa angka untuk diolah melalui proses statistik (Noor, 2015). Penelitian korelasional merupakan penelitian untuk mencari tahu hubungan, asosiasi maupun interdependensi dari dua atau lebih aspek dari suatu fenomena (Ghofur, 2019). Hubungan yang akan dicari penelitian ini adalah antara variabel Motivasi Belajar (X1) dan Lingkungan Belajar (X2) terhadap Hasil Belajar (Y).

Populasi merupakan suatu wilayah yang berisi subjek dan objek dengan karakteristik yang sesuai dengan penentuan dari peneliti guna dipelajari serta diambil kesimpulan (Sugiyono, 2018). Populasi di sini ialah siswa kelas X Labschool Unesa dimana jumlahnya sebanyak 30 siswa.

Sebagian dari populasi guna mewakili untuk diteliti disebut dengan sampel penelitian (Sugiyono, 2018). Penelitian ini menggunakan sampel seluruh anggota populasi tanpa terkecuali yang disebut dengan teknik total sampling. Biasanya digunakan jika jumlah populasi yang relatif sedikit yaitu tidak lebih dari 30 orang.

Data terdiri dari data primer dan sekunder. Untuk memperoleh data primer caranya dengan menyebar kuesioner ke siswa kelas X Labschool Unesa selaku responden yang kemudian dikumpulkan, diolah dan disajikan. Angket atau kuesioner merupakan teknik untuk menghimpun data dengan menyebar sejumlah pernyataan atau pertanyaan ke responden (Sugiyono, 2018). Lalu untuk data sekunder penelitian ini menggunakan hasil PHB (Penilaian Harian Bersama) siswa kelas tersebut yang diperoleh melalui guru pengajar mata pelajaran Ekonomi.

Skala Likert dipilih dalam mengatur jawaban pernyataan dalam kuesioner guna mengukur pendapat atau persepsi serta sikap responden kepada suatu fenomena yang sebelumnya sudah ditetapkan oleh peneliti (Siregar, 2016). Fenomena tersebut adalah variabel penelitian yang pada skala Likert akan diurai menjadi indikator-indikator selanjutnya dijabarkan lagi menjadi instrumen berupa butir-butir pernyataan atau pertanyaan yang kemudian diisi responden.

Kuesioner total berisi 59 pernyataan yang terdiri dari 23 instrumen variabel motivasi belajar dan 36 instrumen variabel lingkungan belajar. Kuesioner sebelum disebarkan ke sampel penelitian akan dilakukan uji validitas dan reliabilitas dulu untuk mengukur seberapa layak dan apakah dapat digunakan dengan menyebarkan ke responden luar sampel dengan karakteristik yang hampir sama.

Pernyataan yang valid dan reliabel akan disebar ke sampel penelitian, kemudian data yang sudah dikumpulkan akan dianalisis regresi berganda terlebih dahulu kemudian diuji asumsi berupa uji normalitas, linieritas, multikolinieritas, heteroskedatisitas serta autokorelasi. Setelah itu diuji hipotesis dengan uji t, F dan R Square. Semua uji menggunakan aplikasi IBM SPSS 24.

\section{HASIL DAN PEMBAHASAN PENELITIAN}

\section{Uji Instrumen Penelitian}

Pengujian instrumen penelitian yang pertama adalah uji validitas. Jumlah responden sebanyak 37 orang. Penentuan hasil berdasarkan $r$ Tabel pada taraf signifikasi 5\% dengan jumlah $N 37$ yaitu 0,3246. Apabila item pernyataan nilai $\mathrm{r}$ hitungnya (Pearson Correlation) $<0,3246$ ( $\mathrm{r}$ tabel) berarti tidak valid atau gugur, pun sebaliknya item pertanyaan yang nilai $r$ hitungnya lebih dari 0,3246 berarti valid.

Pengujian menunjukkan bahwa ada 17 item instrumen variabel motivasi belajar yang valid dan ada 6 item instrumen yang tidak valid. Kemudian ada 22 item instrumen variabel lingkungan belajar yang valid dan ada 14 item instrumen yang tidak valid. Jadi total ada 39 instrumen penelitian yang akan disebar ke sampel penelitian.

Pengujian instrumen penelitian selanjutnya adalah uji reliabilitas yang hasilnya disajikan pada tabel 1 . Diketahui nilai Cronbach's Alpha variabel motivasi belajar (X1) sebesar 0,813. Menurut Sujarweni (2014) suatu kuesioner dinyatakan reliabel atau lolos uji reliabilitas apabila memiliki nilainya $>0,60$. Kesimpulannya kuesioner tersebut reliabel. 
1573 Pengaruh Motivasi Belajar dan Lingkungan Belajar Terhadap Hasil Belajar Mata Pelajaran Ekonomi Siswa Saat Pembelajaran Daring - Heru Jaka Pratama, Muhammad Abdul Ghofur

DOI: https://doi.org/10.31004/edukatif.v3i4.621

Tabel 1

Hasil Uji Reliabilitas

\begin{tabular}{ccc}
\hline Variabel & $\begin{array}{c}\text { Cronbach's } \\
\text { Alpha }\end{array}$ & N of Items \\
\hline X1 & 0,813 & 17 \\
\hline X2 & 0,843 & 22 \\
\hline
\end{tabular}

Diketahui nilai Cronbach's Alpha variabel lingkungan belajar (X2) sebesar 0,843. Nilai > 0,60 disimpulkan kuesioner tersebut reliabel.

\section{Uji Asumsi Model Regresi}

Asumsi model regresi yang diuji dalam penelitian ini adalah uji normalitas residual, linieritas model, multikolinieritas, heteroskedastisitas, dan autokorelasi. Ringkasan hasil pengujian asumsi ini adalah sebagai berikut:

Tabel 2

Hasil Uji Normalitas

\begin{tabular}{lr}
\hline & Unstandardized Residual \\
\hline $\mathrm{N}$ & 30 \\
\hline Asymp. Sig. (2-tailed) & 0,056 \\
\hline
\end{tabular}

Berdasar pada hasil uji normalitas pada tabel 2, diketahui nilai signifikansi sebesar 0,056. Apabila nilainya $>0,05$ berarti nilai residual model regresi berdistribusi normal. Kesimpulannya adalah bahwa residual model regresi ini berdistribusi normal.

Tabel 3. Hasil Uji Linieritas X1

\begin{tabular}{l|l|l}
\hline \multicolumn{2}{|c|}{} & Sig. \\
\hline Hasil Belajar * Motivasi & Deviation from Linearity & 0,639 \\
\hline
\end{tabular}

Dari tabel 3 dapat diketahui nilai Signifikansi Deviation from Linearity sebesar 0,639. Jika nilainya > 0,05 artinya hubungan linier. Maka dapat disimpulkan terdapat hubungan yang linier di antara Motivasi Belajar (X1) dengan Hasil Belajar (Y).

Tabel 4

Hasil Uji Linieritas X2

\begin{tabular}{l|l|c}
\hline \multicolumn{2}{|c|}{} & Sig. \\
\hline Hasil Belajar * Lingkungan & Deviation from Linearity & 0,941 \\
\hline
\end{tabular}

Berdasarkan pada tabel 4 diketahui nilai Signifikansi Deviation from Linearity sebesar 0,941. Jika nilainya $>0,05$ artinya hubungan linier. kesimpulannya terdapat hubungan yang linier di antara variabel Lingkungan Belajar (X2) dan variabel Hasil Belajar (Y).

Tabel 5

Hasil Uji Multikolinieritas

\begin{tabular}{lr}
\hline & VIF \\
\hline Motivasi Belajar (X1) & 1,193 \\
\hline Lingkungan Belajar (X2) & 1,193 \\
\hline
\end{tabular}

Dari ringkasan hasil uji multikolinieritas pada tabel 5 diketahui nilai VIF variabel X1 dan X2 samasama sebesar 1,193. Nilai VIF > 10,00 Berarti tidak terjadi masalah multikolinieritas. Kesimpulannya tidak ada masalah multikolinieritas di antara variabel tersebut.

Tabel 6

Hasil Uji Heteroskedastisitas

\begin{tabular}{lrrr}
\hline Model & R & R Square & Sum of Squares \\
\hline 1 & $0,143^{\mathrm{a}}$ & 0,020 & 135,503 \\
\hline
\end{tabular}


1574 Pengaruh Motivasi Belajar dan Lingkungan Belajar Terhadap Hasil Belajar Mata Pelajaran Ekonomi Siswa Saat Pembelajaran Daring - Heru Jaka Pratama, Muhammad Abdul Ghofur

DOI: https://doi.org/10.31004/edukatif.v3i4.621

Hasil uji heteroskedastisitas di tabel 6 memberikan informasi sebagai berikut : 1) nilai $\mathrm{R} 2=0,020,2$ ) nilai TSS (Total Sum of Squares) $=135,503,3$ ) nilai ESS (Explained Sum of Squares) $=$ R2 $x$ TSS $=2,710,4$ ) Nilai X2 hitung $=\mathrm{ESS} / 2=1,355,5)$ Nilai X2 tabel dengan df sebanyak 2 dan taraf signifikansi 5\% $=5,991$. menurut teori Breuch-Pagan-Godfrey Nilai X2 hitung $<$ X2 tabel berarti tidak terjadi masalah heteroskedastisitas. Maka dapat disimpulkan bahwa 2,710<5,991 artinya tidak terjadi masalah heteroskedastisitas pada data penelitian ini.

Untuk uji asumsi tidak terjadi autokorelasi diantara residual, hasilnya bisa dilihat di tabel 7. Pada tabel tersebut diketahui nilai Durbin-Watson sebesar 2,012. Lalu menurut tabel durbin-watson untuk 2 variabel Independen dengan jumlah responden 30 , nilai dL nya sebesar 1,284 dan nilai dU nya sebesar 1,567 , sehingga dapat dibuat tabel sebagai berikut:

Tabel 7

Hasil Uji Autokorelasi

\begin{tabular}{ccccc}
\hline $\mathrm{d}$ & $\mathrm{dL}$ & $\mathrm{dU}$ & $4-\mathrm{dL}$ & $4-\mathrm{dU}$ \\
\hline 2,012 & 1,284 & 1,567 & 2,716 & 2,433 \\
\hline
\end{tabular}

Apabila nilai $\mathrm{dU}<\mathrm{d}<4-\mathrm{dU}$ tidak terdapat masalah autokorelasi. Maka dapat disimpulkan 1,284 < $2,012<2,433$ artinya tidak terjadi masalah autokorelasi di data penelitian ini.

\section{Uji Hipotesis Model Regresi}

Melalui hasil uji t pada model persamaan regresi pada tabel 8. giketahui nilai signifikansi variabel Motivasi Belajar (X1) Sebesar 0,028 dan nilai t hitungnya sebesar 2,328. Apabila nilai signifikansi < 0,05 dan nilai $\mathrm{t}$ hitung > 2,052 (t tabel) maka H0 ditolak dan H1 diterima. Kesimpulannya Motivasi Belajar berpengaruh positif dan signifikan secara parsial terhadap Hasil Belajar.

Kemudian untuk variabel Lingkungan Belajar (X2) memiliki nilai signifikansi sebesar 0,004 dan nilai t hitungnya sebesar 3,136. Nilai signifikansi < 0,05 dan nilai t hitung $>2,052$ (t tabel) maka H0 ditolak dan H1 diterima. Kesimpulannya Lingkungan Belajar berpengaruh positif dan signifikan secara parsial terhadap Hasil Belajar.

Tabel 8

Hasil Uji t

\begin{tabular}{|c|c|c|c|c|c|c|}
\hline \multirow{2}{*}{\multicolumn{2}{|c|}{ Model }} & \multicolumn{2}{|c|}{$\begin{array}{l}\text { Unstandardized } \\
\text { Coefficients }\end{array}$} & \multirow{2}{*}{$\begin{array}{c}\begin{array}{c}\text { Standardized } \\
\text { Coefficients }\end{array} \\
\text { Beta } \\
\end{array}$} & \multirow[b]{2}{*}{$\mathrm{t}$} & \multirow[b]{2}{*}{ Sig. } \\
\hline & & B & Std. Error & & & \\
\hline \multirow[t]{3}{*}{1} & (Constant) & $-25,816$ & 17,947 & & $-1,439$ & 0,162 \\
\hline & Motivasi & 0,434 & 0,187 & 0,352 & 2,328 & 0,028 \\
\hline & Lingkungan & 0,760 & 0,242 & 0,474 & 3,136 & 0,004 \\
\hline
\end{tabular}

Berdasarkan ringkasan hasil uji $\mathrm{F}$ di tabel 9 dengan nilai signifikansi sebesar 0,000 dan nilai $\mathrm{F}$ hitung sebesar 12,610. Apabila nilai signifikansi < 0,05 dan nilai $\mathrm{F}$ hitung $>3,35$ (F tabel) maka H0 ditolak dan $\mathrm{H} 1$ diterima. Kesimpulannya yaitu Motivasi Belajar dan Lingkungan Belajar secara bersama-sama (simultan) berpengaruh positif dan signifikan terhadap Hasil Belajar.

Tabel 9

Hasil Uji F

\begin{tabular}{l|l|r|r|r|r|c}
\hline \multicolumn{2}{l|}{ Model } & \multicolumn{1}{c|}{$\begin{array}{c}\text { Sum of } \\
\text { Squares }\end{array}$} & df & $\begin{array}{c}\text { Mean } \\
\text { Square }\end{array}$ & F & Sig. \\
\hline \multirow{2}{*}{1} & Regression & 2290,846 & 2 & 1145,423 & 12,610 & $0,000^{\mathrm{b}}$ \\
\cline { 2 - 7 } & Residual & 2452,620 & 27 & 90,838 & & \\
\cline { 2 - 7 } & Total & 4743,467 & 29 & & & \\
\hline
\end{tabular}


1575 Pengaruh Motivasi Belajar dan Lingkungan Belajar Terhadap Hasil Belajar Mata Pelajaran Ekonomi Siswa Saat Pembelajaran Daring - Heru Jaka Pratama, Muhammad Abdul Ghofur

DOI: https://doi.org/10.31004/edukatif.v3i4.621

Untuk koefisien determinasi dengan menggunakan nilai R Square pada tabel 10, dengan sebesar 0,483, yang artinya Motivasi Belajar dan Lingkungan Belajar berpengaruh sebesar 48,3\% terhadap Hasil Belajar, lalu untuk 51,7\% lainnya dipengaruhi variabel yang tidak dibahas di sini.

Tabel 10

Hasil Uji R Square

\begin{tabular}{lrrrr}
\hline Model & R & R Square & $\begin{array}{c}\text { Adjusted R } \\
\text { Square }\end{array}$ & \multicolumn{2}{c}{$\begin{array}{c}\text { Std. Error of the } \\
\text { Estimate }\end{array}$} \\
\hline 1 & $0,695^{\mathrm{a}}$ & 0,483 & 0,445 & \\
\hline
\end{tabular}

\section{Pembahasan}

Penelitian ini mendukung penelitian Nafisah dkk. (2015), Islamiyah (2019) dan Efriza dkk. (2020) yang semuanya menemukan pengaruh yang positif serta signifikan dari motivasi belajar kepada hasil. Meskipun pada saat penelitian ini di laksanakan pembelajaran dilakukan secara daring namun motivasi belajar tetaplah penting dalam meningkatkan hasil belajar siswa. Hasrat, dorongan dan harapan dari dalam diri siswa adalah kunci untuk membuka kesempatan siswa mendapatkan hasil belajar maksimal. Pembelajaran yang dilaksanakan di rumah melalui layar gadget juga mengharuskan guru untuk membuat kegiatan menarik saat belajar, kemudian lingkungan rumah sebagai tempat belajar harus kondusif serta perlunya memberi berbagai bentuk penghargaan dalam belajar agar motivasi belajar siswa meningkat sehingga hasil belajarnya pun ikut meningkat.

Masalah hasil belajar yang belum baik dan bahkan menurun selama pembelajaran daring di masa pandemi ini dapat diperbaiki dengan cara meningkatkan motivasi belajar siswa. Hal tersebut sesuai dengan teori Behaviorisme yang menyatakan bahwa motivasi sangat penting untuk mendorong siswa menunjukkan perilaku atau hasil belajar yang diharapkan.

Penelitian ini sejalan penelitian Anggraini dkk. (2017), Silvia dkk. (2018), Nurdin dan Munzir (2019), Afrinaval dan Syamwil (2019) serta Hermawan dkk. (2020) yang menemukan pengaruh positif serta signifikan dari lingkungan belajar kepada hasil belajar. Meskipun pada saat penelitian dilakukan pembelajaran dilakukan di rumah namun hubungan antara guru dengan siswa, hubungan di antara siswa satu sama lain dan metode serta alat belajar harus baik untuk mendukung belajar siswa serta meningkatkan hasil belajarnya. Terlebih bagi lingkungan keluarga tempat siswa menghabiskan waktu harus terjaga hubungan yang baik antar anggota keluarganya serta pendidikan dan perhatian orang tua harus baik juga untuk mendorong hasil belajar siswa semakin baik. Dan yang terakhir kegiatan masyarakat yang diikuti siswa, teman bergaulnya serta kehidupan yang baik di masyarakat membantu siswa meraih hasil belajar yang baik pula.

Permasalahan yang terjadi selama pembelajaran daring yakni hasil belajar yang belum baik dapat diperbaiki dengan cara memperhatikan lingkungan belajar siswa yang terdiri dari lingkungan sekolah, keluarga dan masyarakat agar terjaga dan mendukung siswa dalam belajar. Sesuai dengan teori Kognitif yang menyatakan bahwa pengetahuan dalam diri individu adalah akibat dari interaksi dengan lingkungan secara berkelanjutan. Begitu juga dengan teori behaviorisme yakni berubahnya tingkah laku siswa yang dicerminkan melalui hasil belajar adalah akibat interaksi dengan lingkungannya.

Hasil penelitian menunjukkan motivasi belajar dan lingkungan belajar adalah faktor yang penting dan signifikan untuk meningkatkan hasil belajar. Ini adalah temuan penting dalam pembelajaran di masa pandemi. Ketika motivasi dan lingkungan belajar seorang siswa baik maka hasil belajarnya juga akan baik. Pengaruh sebesar $48.3 \%$ terhadap hasil belajar menunjukkan bahwa begitu penting kedua faktor ini untuk diperhatikan sebab berpengaruh besar terhadap hasil belajar.

Pada pembelajaran dari di masa pandemi, kedua variabel ini harus menjadi perhatian guru, orang tua, dan juga sekolah. Guru harus mempertimbangkan model pembelajaran apa yang sesuai dengan lingkungan siswa. Misalnya pembelajaran yang lebih fleksibel dan dinamis, sehingga siswa bisa lebih leluasa untuk menentukan kapan dan di mana mereka harus belajar. 
1576 Pengaruh Motivasi Belajar dan Lingkungan Belajar Terhadap Hasil Belajar Mata Pelajaran Ekonomi Siswa Saat Pembelajaran Daring - Heru Jaka Pratama, Muhammad Abdul Ghofur

DOI: https://doi.org/10.31004/edukatif.v3i4.621

Untuk orang tua, mereka harus bisa menyediakan lingkungan yang kondusif untuk belajar dari rumah serta memotivasi anaknya dalam proses pembelajaran. Lingkungan ini tidak hanya masalah fasilitas, tetapi bagaimana mereka mendukung proses pembelajaran anak, menciptakan kondisi yang tidak gaduh, suasana yang hangat dan tidak memberi mereka tekanan yang berlebih.

Penelitian ini dilakukan dengan subyek yang terbatas. Jadi, belum bisa dilakukan generalisasi yang lebih luas. Namun, setidaknya memberikan sumbangan empiris bahwa motivasi belajar dan lingkungan belajar adalah faktor yang penting dalam pembelajaran daring.

\section{KESIMPULAN}

Hasil belajar yang belum mencapai KKM dan bahkan menurun akibat perubahan yang begitu cepat dari pembelajaran tatap muka ke pembelajaran daring di masa pandemi ini dapat diperbaiki dengan cara meningkatkan motivasi belajar siswa dan hasil belajar siswa. Terbukti dari hasil uji hipotesis yang menyatakan bahwa motivasi belajar dan lingkungan belajar berpengaruh positif serta signifikan terhadap hasil belajar dengan kontribusi yang cukup besar. Penelitian ini memperkuat teori Behaviorisme dan teori Kognitif yang keduanya menyatakan bahwa motivasi belajar dan lingkungan belajar memiliki peran sangat penting dalam membuat hasil belajar siswa menjadi baik.

\section{DAFTAR PUSTAKA}

Afrinaval, G., \& Syamwil. (2019). Pengaruh Kebiasaan Belajar dan Lingkungan Belajar Terhadap Prestasi Belajar Siswa Pada Mata Pelajaran Praktikum Akuntansi Jasa, Dagang Dan Manufaktur Siswa Kelas XI Akuntansi Keuangan Lembaga di SMK Negeri 2 Pariaman Tahun Ajaran 2018/2019. Jurnal EcoGen, 2(4), 624-633.

Aminah, S. (2018). Efektivitas Metode Eksperimen Dalam Meningkatkan Hasil Belajar Pada Pembelajaran Ilmu Pengetahuan Alam di Sekolah Dasar. Jurnal Indragiri, 1(4).

Anggraini, Y., Patmanthara, S., \& Purnomo. (2017). Pengaruh Lingkungan Belajar Dan Disiplin Belajar Terhadap Hasil Belajar Kompetensi Keahlian Elektronika Industri Di Sekolah Menengah Kejuruan. Jurnal Pendidikan: Teori, Penelitian, Dan Pengembangan, 2(12), 1650-1655.

Chung, E., Noor, N. M., \& Vloreen, N. M. (2020). Are You Ready? An Assessment of Online Learning Readiness among University Students. International Journal of Academic Research in Progressive Education and Development, 9(1), 301-317.

Chung, E., Subramaniam, G., \& Dass, L. C. (2020). Online Learning Readiness among University Students in Malaysia amidst COVID-19. Asian Journal of University Education, 19. https://eric.ed.gov/?id=EJ1267359

Djamarah, S. B. (2015). Psikologi Belajar. Rineka Cipta.

Efriza, R., Caska, \& Makhdalena. (2020). Analysis of Factors Affecting Student Learning Achievement of Social Sciences Subjects in Muhammadiyah Middle School Rokan Hulu Regency. Journal of Educational Sciences, 4(3), 529-540. https://doi.org/: https://doi.org/10.31258/jes.4.3.p.529-540

Ghofur, M. A. (2019). Penggolongan Jenis-Jenis Penelitian. Maglearning.Id. https://maglearning.id/2019/01/25/penggolongan-jenis-penelitian/

Ginder, S., \& Stearns, C. (2014). Enrollment in Distance Education Courses, by State: Fall 2012. National Center for Educational Statistics, 1-43. http://nces.ed.gov/pubs2014/2014023.pdf

Gunawan, Kustiani, L., \& Hariani, L. S. (2018). Faktor-Faktor Yang Mempengaruhi Hasil Belajar Siswa. Jurnal Penelitian Dan Pendidikan IPS (JPPI), 12(1), 14-22.

Hamalik, O. (2012). Proses Belajar Mengajar. Bumi Aksara.

He, W., Xu, G., \& Kruck, S. E. (2019). Online IS education for the 21st century. Journal of Information 
1577 Pengaruh Motivasi Belajar dan Lingkungan Belajar Terhadap Hasil Belajar Mata Pelajaran Ekonomi Siswa Saat Pembelajaran Daring - Heru Jaka Pratama, Muhammad Abdul Ghofur

DOI: https://doi.org/10.31004/edukatif.v3i4.621

Systems Education, 25(2).

Hermawan, Y., Suherti, H., \& Gumilar, R. (2020). Pengaruh Lingkungan Keluaga, Lingkungan Kampus, Lingkungan Masyaakat Terhadap Prestasi Belajar Mahasiswa. Jurnal Edukasi: Ekonomi, Pendidikan Dan Akuntansi, 8(1), 51-58.

Islamiyah, N. (2019). Pengaruh Fasilitas Belajar dan Motivasi Belajar Terhadap Prestasi Belajar Mahasiswa Jurusan Pendidikan Ekonomi 2017 Universitas Negeri Surabaya. JPEKA: Jurnal Pendidikan Ekonomi, Manajemen Dan Keuangan, 3(1).

Mustofa, M. I., Chodzirin, M., Sayekti, L., \& Fauzan, R. (2019). Formulasi Model Perkuliahan Daring Sebagai Upaya Menekan Disparitas Kualitas Perguruan Tinggi. Walisongo Journal of Information Technology, 1(2), 151. https://doi.org/10.21580/wjit.2019.1.2.4067

Nafisah, K., Margunani, \& Lyna, L. (2015). Faktor-Faktor Yang Mempengaruhi Hasil Belajar Akuntansi Siswa Kelas XI Program Keahlian Akuntansi SMK Negeri 2 Semarang. 4(1), 178-184.

Negoro, S. T. (2004). Anak Super Normal dan Pro Pendidikan. Bina Aksara.

Noor, J. (2015). Metodologi Penelitian Skripsi, Tesis, Desertasi dan Karya Ilmiah. Prenada Media Group.

Nurdin, \& Munzir. (2019). Pengaruh Lingkungan Belajar dan Kesiapan Belajar Terhadap Prestasi Belajar Ilmu Pengetahan Sosial. Faktor Jurnal Ilmiah Kependidikan, 6(3), 247-254

O’Sullivan, J. T., \& Howe, M. L. (1996). Causal Attribution and reading Achievement: Individual Differences in Low-Income Families. Contemporary Educational Psychology.

Parawansa, K. I. (2020). Surat Edaran Gubernur Jawa Timur.

Rosleny, M. (2008). Hubungan Antara Gaya Atribusi Dengan Tingkat Prestasi Akademik. Psympathic, Jurnal Ilmiah Psikologi Pendidikan Dan Perkembangan, 1(1).

Sahu, P. (2020). Closure of Universities Due to Coronavirus Disease 2019 (COVID-19): Impact on Education and Mental Health of Students and Academic Staff. Cureus.

Samsuar. (2019). ATRIBUSI. Jurnal Network Media, 2(1).

Sardiman. (2011). Interaksi Dan Motivasi Belajar-Mengajar (PT Rajagra).

Silvia, N., Suarman, \& Kartikowati, S. (2018). The Influence Of Learning Environment And Discipline Learning On The Results Of Learning Class X IIS Students On Economic Lessons In SMA Negeri 4 Pekanbaru. JOM FKIP UNRI, 5(2), 1-10.

Siregar, S. (2016). Statistika Deskriptif untuk Penelitian Dilengkapi Perhitungan Manual dan Aplikasi SPSS Versi 17. Raja Grafindo Persada.

Slameto. (2013). Belajar dan Faktor-Faktor Yang Mempengaruhinya. Rineka Cipta.

Sugiyono. (2018). Metode Penelitian Kuantitatif. Alfabeta.

Sujarweni, V. W. (2014). SPSS untuk Penelitian. Pustaka Baru Press.

Susanto, A. (2013). Teori Belajar dan Pembelajaran di Sekolah Dasar. Prenada Media Group.

Tu’u, T. (2004). Peran Disiplin pada Perilaku dan Prestasi Siswa. Rineka Cipta.

Uno, H. B. (2016). Teori Motivasi \& Pengukurannya Analisis di Bidang Pendidikan. Bumi Aksara.

Wijaya, O. P., \& Bukhori, I. (2017). Effect of Learning Motivation, Family Factor, School Factor, and Community Factor on Student Learning Outcomes on Productive Subjects. Jurnal Pendidikan Bisnis Dan Manajemen, 3(3), 192-202.

Winkel, W. S. (1996). Psikologi Pendidikan. Gramedia. 